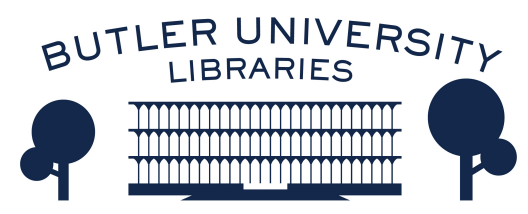

Journal of Hindu-Christian Studies

Volume 7

Article 15

January 1994

\title{
Book Review: "Jules Monchanin, Pioneer in Hindu-Christian Dialogue"
}

Harold Coward

Follow this and additional works at: https://digitalcommons.butler.edu/jhcs

Part of the Religion Commons

\section{Recommended Citation}

Coward, Harold (1994) "Book Review: "Jules Monchanin, Pioneer in Hindu-Christian Dialogue"," Journal of Hindu-Christian Studies: Vol. 7, Article 15.

Available at: https://doi.org/10.7825/2164-6279.1103

The Journal of Hindu-Christian Studies is a publication of the Society for Hindu-Christian Studies. The digital version is made available by Digital Commons @ Butler University. For questions about the Journal or the Society, please contact cbauman@butler.edu. For more information about Digital Commons @ Butler University, please contact digitalscholarship@butler.edu. 
whether scholar, student or devotee.

Julius Lipner

Divinity School

University of Cambridge

Jules Monchanin, Pioneer in Hindu-Christian Dialogue. Sten Rodhe, New Delhi: ISPCK, 1993, pp. xvi +76 .

JULES MONCHANIN (1895-1957), the founder of the Shantivanam ashram in Tamil Nadu, came to India in 1939 as a French Catholic priest. His life in India was devoted to integrating the Hindu tradition, especially its sannyasi contemplative practice, into the life of the Christian Church. Bede Griffiths comments about Monchanin that "His knowledge of Indian culture and philosophy was profound, but at the same time he sought to embody his ideal of a meeting between the Hindu philosophical tradition and the Christian faith in a community which would be rooted in the culture of India." Based upon his lifelong study of Hindu-Christian relations and his many visits to the Shantivanam Ashram, Sten Rodhe has written a concise scholarly assessment of Monchanin's life and legacy. This contribution is welcome since the two previous treatments of Monchanin's life by Henri de Lubac and J.G. Weber are both out of print.

After a Foreword by Bede Griffiths, Rodhe's Introduction sets Monchanin's life in the context of the history of Hindu-Christian interaction in India. This clear and concise history is masterfully written. In it.Monchanin is shown to follow in the intellectual and spiritual legacy of the Italian Jesuit Robert de Nobili in attempting to create an Indian Christianity, using Indian customs instead of Western ones. Although for most of this century both the Roman Catholic and Protestant churches in India officially rejected this approach, in recent times both have come close to embracing Monchanin's model for Hindu-Christian interaction.

Chapter one recounts Jules Monchanin's childhood, his strong Catholic spiritual formation and the impact made upon him when at 14 years he read a book on the Buddha. He was a voracious reader of philosophy, theology and mysticism. After studying these subjects at "the grand seminary" near his home in Lyon, he was ordained in 1922. In Christian theology he preferred Augustine the open seeker to Aquinas the systematizer. The next 10 years of his life were engaged first in University study and then in service as a parish priest. While he flourished in the freedom of thought in the University, he found it very hard to get himself to write and never did finish his thesis. This antipathy to writing remained throughout his life - which he explained by saying that he preferred solitude to writing. A lasting friendship during these years was formed with Henri de Lubac. While he identified with the poor of his parishes, even joining them in demonstrations, he was drawn to more academic pursuits. $\mathrm{He}$ joined a philosophical society and wrote papers on topics that remained with him for life: "The one and the many", and "Comparative Mysticism". In an essay on "Forms, Life and Thought" he maintained that religious experience needs forms and structures in the same way as other kinds of life. "Without firm structures spiritual life becomes mere dreaming. Christian life, which tells us to love God and our neighbour as ourselves, to abandon our egoism, is possible only within structures." (p.10) In 1932, Monchanin took ill and near death he promised God that if he were spared he would dedicate his life to the salvation of India.

It took seven more years for Monchanin to convince church authorities to send him to India. But the time was not wasted. He gave lectures in Lyon and at Louvain in which he developed the theology that he later lived in India. That theology is clearly documented in its formation in Chapter 4. Monchanin's dream was to Christianize India, but the approach was markedly different than the missionary theology 
of his day. Rather than carrying with it European forms, the Church had to take on new forms in other cultures. Since the essence of Indian culture was mysticism, the challenge for Christianity in India was to focus on the inner Holy Spirit in its Indian forms and allow the visible form of the Church to express itself in a truly Indian way. In Monchanin's view the revelation of Christ is a fixed entity around which various constellations can be formed European Christianity is one form, Indian Christianity will be another. The role of the missionary then is not to proselytize but to immerse oneself in India so as to help that tradition rethink itself in a Christian way. That, indeed, would mark India's fulfilment. To prepare himself for that task, Monchanin learned Sanskrit before leaving France, so that he would be ready to immerse himself in the deep pool of Hindu spirituality on arrival in India. He learned Sanskrit rather than a popular language because he thought that it was of first importance to win the cultural leaders, the Brahmans. To do so he accepted their ways, including caste, which he suggested would not be absent in a Christian India but simply loose its cruelty. This is the same approach as was taken by Gandhi and is open to the same kinds of critique such as that mounted against Gandhi by Ambedkar.' But Monchanin's lasting contribution was his recognition that to find its Indian form the Church had to start from its invisible form in order to find its visible form. The emphasis had to be on contemplation, but not in its European forms as practiced by Benedictines, Cistercians and others - instead the Christian Spirit must immerse itself in India until pure Indian Christian forms were found. To this task Monchanin dedicated his life.

The rest of the book, chapters 5-10, recounts the way Monchanin's life unfolded in India as he sacrificed himself to the realization of his dream: the rethinking of India in a Christian way and the rethinking and living of Christianity in an Indian way. After learning Tamil and English so that he could communicate with the people, Monchanin served in several village parishes. His theology continued to develop in dialogue with Hindu thought. He made a clear distinction between the Christian concept of incarnation and the Hindu avatar idea which he found to be similar to Marcion's notion of Christ having no real body. He noted the lack of anything parallel to the Christian idea of creation in Hinduism. But he found the Advaita way of symbolizing Brahman as the threefold Sat (Being), Cit (Consciousness) and Ananda (Bliss) useful in Indianizing the Christian concept of Trinity (p.32).

Monchanin often became depressed in India with his ill health, the slowness with which things moved, and the lack of acceptance of his ideas in the Indian Catholic Church. But he took it all as a lesson in patience and endurance of the sort that typified the Indian culture. The beginning of an Indian-style contemplative ashram of the sort he had always dreamed of occurred with the arrival of the Benedictine Henre Le Saux in 1948. Together they began the "Saccidananda Ashram" (the ashram of the Holy Trinity) in "Shantivanam" (the forest of peace). Monchanin was the dreamer and philosopher while Le Saux was the practical organizer and did most of the writing. They adopted the yellow robes of the Indian sannyāsis rather than the white soutane worn by Catholic priests in India. But they were disappointed in the lack of interest from Hindus who were not very interested in Christianity or in Hindu-Christian dialogue - a situation that continues to the present. Instead many Hindus thought that all problems had been solved in the non-duality of Advaita and thus had little interest in a Hinduized version of the Trinity which for them was at the lower saguna level. As Monchanin put it in 1951, "India is not yet interested, it does not understand the Trinitarian God, incarnated in Christ". (p.37) While Le Saux seemed more comfortable with Advaita, and more concerned with contemplation than philosophy, Monchanin held that "Hinduism must reject its equation of atmanbrahman, if it is to enter into Christ." (p.44) After studying Yoga texts (his health was apparently too fragile to allow him to practice it), he found it atheistic, lacking in love and grace, and therefore having little room for engagement with Christianity. Yet he recognized that it was at the core of much Indian spirituality 
and thus posed a serious challenge to his dream of Christianizing India. In spite of that he remained hopeful of the advent of India into the Church, although his vision of India rediscovering itself in a Christianized form faded considerably.

This is a carefully researched, well-written scholarly book which deserves to be recognized as the standard work on Monchanin's life. Careful use is made of Monchanin's letters and essays, many of which are in French. Rodhe includes a helpful English summary of some of these writings in Chapter 10. Also included is a concise annotated listing of writing about Monchanin. For those interested in the main publication coming out of the ashram, "An Indian Benedictine Ashram", which was published in English and French with several revisions, chapter 8 offers a close reading and critical literary analysis of the text. The work states the main aim of the ashram as the reception and preparation of Indian monks to stand before God in prayer and adoration in the name of a Christianized India. (p.54) However, notes Rodhe, "To their disappointment these monks never arrived" (p.54). Monchanin's health declined rapidly in 1957 due to cancer. $\mathrm{He}$ died in Paris that year realizing that his vision of a Christianized India had not even begun to be realized, and perhaps never would be. But he also saw himself as like Moses who died before entering the promised land yet hopeful that others would go on where he had not succeeded. Toward himself he was ruthless in his determination to live as an Indian, under an Indian bishop, and not under any kind of European mission venture. In this he was unique and successful. He had a brilliant mind and a deep mystical vision but one that due to his poor command of Tamil and English he rarely was able to communicate to those around him.

Of Monchanin Bede Griffiths said, "he has left behind him the witness to an ideal, like that of de Nobili and Brahmabandhav Upadhyaya, which it seems to me can only grow in its significance as the years go by." (p.64) Rodhe concludes, "Monchanin was a pioneer in the Catholic Church of an inclusive view of the relation between Christianity and Hinduism. The Indian tradition should not be rejected but integrated in the Church." (p.73) Something of Monchanin's contribution may be seen in the fact that after his death this view became the official position of the Catholic Church at the Second Vatican Council.

\section{Harold Coward \\ University of Victoria}

\section{Note}

1. B.R. Ambedkar, "Annihilation of Caste" (New Delhi: Arnold Pub., 1990). Letters between Gandhi and Ambedkar are included in the book.

Encountering God: A Spiritual Journey from Bozeman to Banaras. Diana Eck. Boston: Beacon Press, 1993, pp.xv +259.

SELDOM DO WE read a book that lifts us to new levels of understanding - a book that evokes the complexity of the Hindu-Christian encounter so fully and sensitively that we are surprised and inspired by a fresh recognition of our own lives in its words. Encountering God is such a book. Perhaps Diana Eck's new book had such a profound impact upon me because of the close parallel of my experience with hers. Beginning life from a deeply spiritual Christian boyhood in the remote foothills of the Canadian
Rockies (less than 300 miles North of Diana Eck's childhood home of Bozeman, Montana), I soon had my strong but naive Christianity challenged, broadened and deepened as I studied Hindu philosophy with Professor T.R.V. Murti at Banaras. Now, many years later I seek, within the evolving context of that encounter, an adequate expression for the religious pluralism of our modern world. While previous books by Wilfrid Smith, John Hick, Paul Knitter and Raimundo Panikkar have moved us forward, 